\title{
Boosting the entrepreneurial scene in cities: experiences and reflections from the InFocus network - a short communication
}

\author{
Author(s) \\ Van Winden, Willem \\ DOI
}

10.1504/IJKBD.2019.100988

\section{Publication date}

2019

\section{Document Version}

Final published version

\section{Published in}

International Journal of Knowledge-Based Development

\section{Link to publication}

Citation for published version (APA):

Van Winden, W. (2019). Boosting the entrepreneurial scene in cities: experiences and reflections from the InFocus network - a short communication. International Journal of Knowledge-Based

Development, 10(2), 97-106.

https://doi.org/10.1504/IJKBD.2019.100988

It is not permitted to download or to forward/distribute the text or part of it without the consent of the author(s) and/or copyright holder(s), other than for strictly personal, individual use, unless the work is under an open content license (like Creative Commons).

If you believe that digital publication of certain material infringes any of your rights or (privacy) interests,

please let the Library know, stating your reasons. In case of a legitimate complaint, the Library will make the material inaccessible and/or remove it from the website. Please contact the library:

https://www.amsterdamuas.com/library/contact/questions, or send a letter to: University Library (Library of the University of Amsterdam and Amsterdam University of Applied Sciences), Secretariat, Singel 425, 1012 WP Amsterdam, The Netherlands. You will be contacted as soon as possible. 


\title{
Boosting the entrepreneurial scene in cities: experiences and reflections from the InFocus network - a short communication
}

\author{
Willem Van Winden \\ Centre for Applied Research on Economics and \\ Management - CAREM, \\ Amsterdam University of Applied Sciences, \\ Room 07A08, P.O. Box 1025 / 1000 BA, \\ Amsterdam, The Netherlands \\ Email: w.van.winden@hva.nl
}

\begin{abstract}
This short communication contains a reflection on local entrepreneurial ecosystems and how to boost them, in the context of smart specialisation strategies of cities and regions. It is based on a literature study and inputs from ten member cities of the InFocus project (sponsored by the EU's URBACT programme), that exchange and develop knowledge about the development of smart specialisation strategies on the urban level. In September 2017, the network held a meeting in Turin, dedicated to the topic of promoting entrepreneurship ecosystems. The paper discusses several specific aspects of policies regarding entrepreneurship: the relation with smart specialisation approach, start-up promotion policies, fostering a culture of entrepreneurship, and the different development stages in entrepreneurship: Starting, scaling, and growing, with examples from cities in the InFocus network. Among other things, it concludes that a stronger alignment between the urban and regional policy levels is required to link the urban-focused start-up ecosystems to the regional industrial tissue.
\end{abstract}

Keywords: entrepreneurship ecosystems; start-ups; smart specialisation; cities; incubators; innovation systems; urban innovation; urban policy.

Reference to this paper should be made as follows: Van Winden, W. (2019) 'Boosting the entrepreneurial scene in cities: experiences and reflections from the InFocus network - a short communication', Int. J. Knowledge-Based Development, Vol. 10, No. 2, pp.97-106.

Biographical notes: Willem Van Winden works as a Professor of Urban Economic Innovation at Amsterdam University of Applied Sciences. He obtained his $\mathrm{PhD}$ degree at Tinbergen Institute, Erasmus University Rotterdam. He has published widely on urban knowledge based development and related topics, in books and international peer-reviewed scientific journals. He works as advisor for several cities and organisations, including Urbact, Europe's largest exchange and learning programme promoting sustainable urban development, and EUniverCities, a network of European cities and universities. 


\section{Introduction}

Innovation and entrepreneurship are broadly recognised as core drivers for knowledge-based regional development (Romano et al., 2014). This short communication contains a reflection on local entrepreneurial ecosystems and how to boost them, in the context of smart specialisation strategies of cities and regions. It is based on a literature study and inputs from ten member cities of the InFocus project (Bielsko-Biala, Bilbao, Bordeaux, Bucharest, Frankfurt, Grenoble, Ostrava, Plasencia, Porto, and Turin, sponsored by the EU's URBACT programme), that exchange and develop knowledge about the development of smart specialisation strategies on the urban level, in alignment with the region. In September 2017, the network held a meeting in Turin, dedicated to the topic of promoting entrepreneurship ecosystems.

This paper starts, in Section 2, by elaborating the core idea of the entrepreneurial ecosystem: what is it, and what are its elements and characteristics. Next, in Section 3, we discuss some specific aspects of policies regarding entrepreneurship that we focused on during the workshop: the relation with smart specialisation approach, start-up promotion policies, fostering a culture of entrepreneurship, and the different stages in entrepreneurship: Starting, scaling, growing. Each subsection contains one or more examples from cities in the InFocus network. Section 4 contains the conclusions, and outlines the relevance for the smart specialisation process.

\section{An entrepreneurial ecosystem: what is it?}

What is an entrepreneurial ecosystem? The term has become popular due to the increasing networked nature of our contemporary economy. It reflects the insight that there are many interdependencies between economic actors, and that the success of individual firms depends on their role and interaction with wider (local and regional) networks. It is worthwhile to recall that the word 'ecosystem' is a metaphor, borrowed from the biology field.

A quote from Isenberg (2012, p.1), an influential author on the topic, further explains the analogy: "An ecosystem exists in nature when numerous species of flora and fauna interact in a dynamic, self-adjusting balancing act. Thus, in cities, you need to provide a broad platform to support the inclusive vision, encouraging restaurateurs, designers, neighbourhood groups, schools and universities, real estate developers, law firms and architects, chambers of commerce and other government agencies to interact with each other in innovative ways. Best processes are more important than best practices." An ecosystem is a self-organising, dynamic system, without a central body that makes decisions. Here, we see a difference between an ecosystem approach and a cluster approach. Typically, cluster strategies tend to prioritise a sector, for example clean tech, biotech or ICT. In an ecosystem approach, a specialisation is not predefined but 'emerges' from a continuous interplay, interaction and dialogue between entrepreneurs, knowledge institutes, and others.

After reviewing many studies, OECD (2013, p.5) defines an entrepreneurial ecosystem as "a set of interconnected entrepreneurial actors (both potential and existing), entrepreneurial organisations (e.g., firms, venture capitalists, business angels, banks), institutions (universities, public sector agencies, financial bodies) and entrepreneurial processes (e.g., the business birth rate, numbers of high growth firms." The performance 
of the system can be measured by the number of start-ups, levels of 'blockbuster entrepreneurship', the number of serial entrepreneurs, the number of exits, or venture capital invested.

Applied to cities and regions, OECD (2013) defines several characteristics of the entrepreneurial ecosystem:

- The ecosystem thrives on 'large established businesses', with significant management functions (e.g., head office or divisional/ subsidiary office) as well as R\&D and production activities. These larger businesses play a role as:

1 talent magnets

2 training people

3 source of new business

4 developing the ecosystem's managerial talent pool/providing commercial opportunities for local businesses.

If they fail, they may release a start-up spree (as happened in Helsinki, Eindhoven, or Toronto when big tech firms failed there); The entrepreneurial enrichment to ecosystems provided by corporate failure has been labelled 'whale fall' (Isenberg, 2011).

- The growth of the ecosystem is driven by a process of 'entrepreneurial recycling'. Entrepreneurs who sold their successful companies but remain involved in the local economy, starting another firm, investing in new start-ups and/or helping them with their expertise. Some become business angels, or set up a venture capital fund. They may become advisers, mentors, or entrepreneurship teachers ('pracademics'). Communities of innovation may emerge (Elia et al., 2016).

- Ecosystems are 'information rich'. It is easy to access information and knowledge on demand trends, new technologies, logistics solutions, production and machines, and service and marketing concepts. Being located close to each other in the same region helps to share tacit knowledge (Gertler, 2003). Information is shared through organised and accidental meetings. Moreover, there are 'bridging assets': well-connected and experienced people who can connect people to each other and thus provide for the flow of information and knowledge; they are able to help starters realise their growth potential.

- Successful entrepreneurship ecosystems have cultural aspects, including a culture of inclusiveness, an attitude of 'give-before-you-get', a culture of widely sharing knowledge experience and expertise. The attitude to failure is also critical.

- The availability of finance (a critical mass of investors to provide finance and support in the various development stages of a company) is a key feature of the ecosystem. Important players in the respect are business angels, seed capital funds, or facilitators such as business accelerators.

- Universities also play an important role in entrepreneurial ecosystems. Their most important contribution is the fact that they attract and educate students, who bring new ideas and increase the intellectual capacity of the community. The commercialisation of academic research can also generate new business, but 
numbers of university spin-out companies are typically small and high growth spin-outs are rare (Harrison and Leitch, 2010; Laitinen et al., 2016).

\section{Reflections from the InFocus workshop}

During the in-focus workshop, we exchanged ideas and policy approaches regarding the boosting of local and regional entrepreneurial ecosystems. The workshop was divided into four key sessions. In session 1, 'setting the scene', we discussed the role of entrepreneurship ecosystems in the wider framework of smart specialisation. Session 2 focused on start-up policies, session 3 on the creation of a culture of entrepreneurship, and session 4, finally, dealt with the question of scaling up after the initial setup of a company.

\subsection{Setting the scene: the role of entrepreneurship in the smart specialisation concept}

In the last decade, the concept of 'smart specialisation' has become a key element of the EU's Cohesion Policy. In the current programming period, the EC asks European regions to formulate a smart specialisation strategy, as ex-ante conditionality for access to structural funds (Mieszkovski and Kardas, 2015). The idea of smart specialisation suggests that regions, in their quest for knowledge- and innovation based economic development, must avoid the often-made mistakes of focusing only on infrastructures and buildings, following general policy fashions, or uncritically boosting promising generic innovative growth clusters (ICT, creative industry, biotech). Smart specialisation implies that regions focus on economic activities where they have particular strengths, try to make these activities more innovative, knowledge-based, by aligning them to the regional knowledge infrastructure. Also, a smart specialisation strategy should promote private investment in $R \& D$ and innovation. This form of specialisation helps to realise the potential for scale, scope and spillovers in knowledge production and use (the most important drivers of productivity in R\&D and innovation-related activities). Smart specialisation is important to develop distinctive and original areas of specialisation for the future: every region is unique, and must find its own unique path to innovation. Smart specialisation thus involves both a logic of concentration and a logic of particularisation of a region's knowledge assets.

In the smart specialisation concept, entrepreneurship plays a double role. First, entrepreneurship is the cornerstone of the urban and regional economy (Romano et al., 2014). Entrepreneurial activities of established firms, start-ups and other stakeholders are the basis for economic and social value creation. Entrepreneurs are key actors driving the economic specialisation of the city of the region. This is especially - though not exclusively - the case for entrepreneurs in knowledge-based sectors and industries, where better alignment and collaboration with knowledge institutes and universities might lead to more innovation. In the smart specialisation approach, deeper entrepreneurial collaborations between firms and knowledge actors are seen as seen as drivers for innovation, and may also help to focus or redirect investments in knowledge resources in fields where private entrepreneurship is strong, in order to further develop unique strengths together (McCann and Ortega-Argilés, 2011). Second, on a higher level of abstraction, a key aspect of the smart specialisation concept is the entrepreneurial 
discovery process. This is the process by which local and regional policymakers 'discover', together with stakeholders, new promising economic opportunities in which the city or region might invest (Foray et al, 2011). The entrepreneurial discovery process implies that urban/regional economic policies and investment decisions should not be made in the ivory tower of city hall or regional government, but rather be based on an open, collective and on-going 'search' for new opportunities.

Box 1

Bilbao's entrepreneurial discovery process

In 2014, the City of Bilbao organised a cluster prioritisation exercise. In a large process of consultation with many stakeholders, six priority areas were defined, in which Bilbao would invest in the years after. Some of them are already well developed, some are more in an emerging phase. But more interesting than the outcome is the process. Bilbao Ekintza (BE), the city's development company, acted as facilitator of the prioritisation process. But also after the selection of the priority areas, $\mathrm{BE}$ is still active as broker and facilitator of a process in which many stakeholders concretely develop projects and actions within that specialisation. As part of the InFocus project, the efforts are further narrowed down to three priority sectors: Cultural and Creative Industries, Advanced Services, and Digital Economy. These areas are selected because they overlap with the sectoral focus of the region, the Basque Country. This reflects the ambition to achieve a better alignment between urban and the regional level-one of the key aims of the InFocus project.

BE's strategic sectors team is organised in three groups, each one responsible for the further development of one priority sector. Each group is in charge of organising the "entrepreneurial discoveries' in their field. The work of each theme starts with the generation of sector intelligence, i.e., retrieving, collecting and interpreting knowledge and insights from entrepreneurs that work in that sector. This is not easy: it requires a lot of interaction, and the ability of team members to interpret the information they gain from the entrepreneurs. And, it is a continuous process, as new developments happen every day and the team must remain up-to-date. Also, each team identifies the key actors, consults them, and seeks to involve them in concrete investment and development projects that support the specialisation. These can be flagship projects, the development of specific spaces for the sector, but also actions in the field of branding, positioning, internationalisation. Again, this is a demanding job: team members must be able to find the right people and organisations, to mobilise them, and to turn ideas into concrete projects and actions.

In sum, doing an entrepreneurial discovery process aks for new, high level competences of the people that lead and guide the process. As Eva Salcido, leader of BE, puts it: "we are still leaning and building together, how the entrepreneurial discovery process can boost the smart specialisation in Bilbao."

\subsection{Supporting start-ups: what is the best policy?}

Start-up support has emerged as key policy area to boost the local entrepreneurial ecosystem. Cities and regions offer a rich range of start-up support, delivered by public and the private sector. The number of incubators has grown. Oxford University Innovation Ltd. (2016) counted 7,000 incubators worldwide. Some are directed at any type of start-up, others are more knowledge or technology oriented; some target specific industries or sectors (Fintech, ICT, Biotech etc.), others are linked to universities, to promote student entrepreneurship, or to commercialise research. Some are run by private actors (banks, commercial incubators that make money from fees, rents and shares); others by the (semi)public sector. Then, there is a plethora of funding sources for start-ups, provided by traditional banks, angel investors, VC funds, and public sector funds. 
During the session, we discussed different forms and types of start-up support. Also, we heard the stories of two entrepreneurs who had recently started their companies. Some key findings from the workshop were the following:

- The recent surge of entrepreneurship in Europe as such is a positive development, but in part it is also a reaction on a poorly functioning labour market. There are indications that many start-ups emerge because there is a lack of regular job opportunities and fixed contracts.

- For start-ups, it can be difficult to understand and navigate through the rich variety of support measures, and find the ones that fit them best. Cities and regions could take action to align the offer, and making it accessible; Frankfurt announced to make a single website with all the start-up support available in region and city; this would help start-ups find their way in the sometime complex and confusing variety of support measures in the city and the region.

- The MIP programme in Turin indicates that the success of more 'mundane' start-ups (i.e., not in high tech of advanced services) can be greatly enhanced when they obtain a small amount of support and coaching; such programmes can also prevent the creation of companies that are probably not viable.

- Most incubation programs focus on funding, business modelling and technology. However, start-ups need also legal support in very practical fields, for example concerning the type of information that must be printed on packages or user manuals. This was a message conveyed by two of the start-ups that presented themselves at the session.

These notions from practitioners resonate with Bathelt and Spigel.(2011), who argue that start-up policy should go beyond promoting academic, research-based spin-offs; rather, a broader view of spin-offs is required; a view that accounts for a larger array of ventures and that looks beyond the firm or university to the broader set of regional structures and relations. They also support the conclusion of Mas-Verdú et al (2015) who found that incubators' impact will depend on tailoring their services to the needs of their target customers (i.e., start-ups).

Box 2 Some examples from InFocus partners

Almost all IN FOCUS partners have policies and programmes in place to promote entrepreneurship, most of them with a strong ecosystem approach. In Turin, Universities play a prominent role promoting the local start up scene, basically through two main facilities, I3P, inside the campus of Politecnico di Torino and one of the biggest incubators in Italy, and 2i3T, linked to Università di Torino. Both incubators have been credited as 'best practice' at EU level In Bilbao, 'Bilbao Auzo Factory' is a network of business centres promoted by Bilbao Ekintza, which are located in different districts across the city. They act as an innovative interface between citizenship, neighbourhood, entrepreneurs and companies. The centres are based in revitalised disused buildings, and each of them has a focus in one of the city's sectoral priorities, e.g., Tourism, Urban Solutions, Health, Creative industries. Bielsko-Biala (Poland) has also taken many initiatives to create a favourable local entrepreneurship ecosystem. The

Bielsko-Biala Development Agency invested in the first technology incubator in Poland (Beskidzki Inkubator Technologiczny BIT); it set up a dedicated web-based platform to attract potential entrepreneurs; It opened the Bielsko-Biała Endorsement Fund to support the small, local businesses and a specific local funding scheme for technology-based start-ups named Techno-BIT Venture. 


\subsection{Fostering a culture of entrepreneurship}

Culture is an important feature of an entrepreneurship ecosystem. In this session, we put the following questions central: What is a culture of entrepreneurship? How to stimulate it? How do policymakers know that they promote it the right way? The starting point is that entrepreneurship is not limited to start-ups. Rather, it is an attitude of recognising new opportunities and then act upon that. This can be embedded in schools, universities (Secundo et al., 2015), companies, but also in the local and regional government.

An important message from the workshop was that a culture of entrepreneurship is fostered when there are concrete physical spaces and places where entrepreneurs, not only starting ones, can meet and interact (Carvalho and Van Winden, 2017). Entrepreneur Rui Couto', explained how a number of entrepreneurs developed 'Founders Founders', a new concept for entrepreneurs that had outgrown the incubation stage. As a group, and supported by the city, they bought a house and redeveloped it as post-incubation space for firms, where they can easily meet each other, exchange knowledge and ideas, and develop common business projects.

The leader of an incubator from Grenoble (and successful founder) stressed that a culture of entrepreneurship asks that (young) people are seduced to become entrepreneurs. An important factor is the visibility of role models: students will opt for a career as entrepreneur when they see how fellow students have done so successfully. Thus, it is important to organise many points, events and moments where this interaction occurs. This must not only be done in dedicated entrepreneurship courses - mostly located at business schools- but across the board of institutes of higher education. A good example is YesDelft ${ }^{2}$, a union/community of entrepreneur-students at Delft University of Technology: they combine student life with starting up a company, and present entrepreneurship 'peer to peer' as realistic career in all study courses at the university.

Finally, entrepreneurship should not only be seen as career opportunity or vehicle to create economic value; entrepreneurs can also be engaged to address societal challenges. The leader from Torino Social Innovation, and 'start-up in residence' showed how the city of Turin seeks to promote this kind of entrepreneurship. One of the key lessons was that providing grants or other financial incentives to not-for-profit entities was not an appropriate avenue; The city shifted to an approach in which urban challenges are defined (for example, the refurbishment of a square), and invites entrepreneurs to develop and deliver a solution, that can be purchased by the city when it works. Amsterdam's Start-up in Residence programme follows a similar track (see Van Winden and de Carvalho, 2018 for an evaluation).

\subsection{Starting, scaling, growing?}

Under this heading we discussed the stage that may come after the start-up stage: scaling up. According to the workshop participants, the problem why scaling often does not happen has several reasons.

Many start-ups are marginal small local business, for example in retail, tourism, or personal services; their founders often have no interest in scaling, they are happy to make a living in their own micro firms. For more knowledge based or tech business, scaling is often an option. However, compared to the US, European firms have difficulties in scaling up. A key issue is that many founders in Europe (and also the support structures) tend to lay too much focus on building the product and the business model, but much less 
on the large scale operational roll-out. It is a blind spot in the mental map. Moreover, large scale rollout requires different competences (in the field of production, logistics, operations), that are often not included in the start-up team. Rui Couto, from Porto's Founders Founders initiative, saw several cases in which US venture funds ask promising European firms to incorporate in the US, scale up their business there; if successful, they will have deep enough pockets to make a large entry in the EU markets.

A business development manager from a Torino scale up in the medtech business pointed at another barrier for scaling: the difficulty to find qualified staff. Search costs are high, and the fresh graduates from the university often lack the practical skills to be of value for the firm, so they need retraining. Also, she underlined that scaling up asks for being active in the right kind of networks. After a 'chat in a café' her company discovered a new application for their testing device, which now constitutes an important market. This point underlines the importance of having an 'information rich' local ecosystem where the chance of such seemingly random encounters is enlarged.

\section{Conclusions and relevance for smart specialisation}

The workshop revealed a number of viable options to improve local and regional entrepreneurial ecosystems, and resulted in concrete suggestions and lessons. Entrepreneurship is a growing phenomenon across the board, especially young people increasingly see it as a viable career option, reflected in the growing numbers of start-ups and the increasing popularity of entrepreneurship-related programmes at universities. The ecosystem approach stresses that entrepreneurs, especially in their early stage, rely on local and regional supporting networks for access to ideas, people, capital, markets and suppliers. The stronger, richer and information-dense these networks, the better the chances that start-ups will thrive. This suggests that the most promising types of start-ups will probably emerge in fields in which the city and region already have strong competences, either in business or in research, or in fields that are strongly related. A striking example mentioned during the workshop is the successful Turin-based start-up that develops GPS trackers for bikes; during its development, it relied on the traditionally strong manufacturing competences in the Turin region for the high-quality manufacturing of the equipment.

This can be read as a recommendation for cities and region to focus their support policies on fields in which the city/region is already specialised. It underlines that regional and urban policymakers must know what and where the specific local economic strengths are, in order to align public sector investments with those of the private sector and knowledge institutes. Also, policymakers should systematically monitor the current situation and new developments, and discover, through a continuing dialogue with many stakeholders, the emergence of new promising fields.

Furthermore, the workshop outcomes hint at the relevance of stronger vertical collaboration between urban and regional policymakers in designing and implementing smart specialisation strategies. The EC designed the smart specialisation framework primarily from a regional, not an urban perspective, and regional authorities are in the driver's seat. However, Europe's growing start-up ecosystems have a strong geographical bias towards core cities, and, as argued in this communication, they play a driving role in the development of urban and regional knowledge economies. Thus, when regional management authorities design and implement smart specialisation strategies, they need 
to take this urban reality into account. A stronger collaboration and alignment between the urban and regional level might also link the urban-centred start-up scene to more traditional industries that are more geographically spread in the region. This could help start-ups to link to clients in the region, and might help established regional firms to get an innovative impetus from start-ups.

\section{References}

Bathelt, H. and Spigel, B. (2011) 'University spin-offs, entrepreneurial environment and start-up policy: the cases of Waterloo and Toronto (Ontario) and Columbus (Ohio)', International Journal of Knowledge-Based Development, Vol. 2, No. 2, pp.202-219.

Carvalho, L. and Van Winden, W. (2017) 'Planned knowledge locations in cities: studying emergence and change', International Journal of Knowledge-Based Development, Vol. 8, No. 1, pp.47-67 [online] http://www.inderscience.com/info/inarticle.php?artid=82429 (accessed 1 February 2018 .

Elia, G., Petti, C. and Sarcina, A. (2016) 'Promoting communities of innovation: do industrial policies matter?', International Journal of Knowledge-Based Development, Vol. 7, No. 3, pp.207-224.

Foray, D., David, P.A. and Hall, B.H. (2011) Smart Specialisation From Academic Idea to Political Instrument, the Surprising Career of a Concept and the Difficulties Involved in its Implementation, No. EPFL-WORKING-170252, EPFL.

Gertler, M. (2003) 'Tacit knowledge and the economic geography of context, or the indefinable tacitness of being (there)', Journal of Economic Geography, Vol. 3, No. 1, pp.75-99.

Harrison, R. and Leitch, C. (2010) 'Voodoo institution or entrepreneurial university? Spin-off companies, the entrepreneurial system and regional development in the UK, Regional Studies, Vol. 44, No. 9, pp.1241-1262.

Isenberg, D. (2011) 'When big companies fall, entrepreneurship rises', Harvard Business Review, [online ]http://blogs.hbr.org/2013/03/when-big-companies-fall-entrep/ (accessed 27 November 2017.

Isenberg, D. (2012) 'Planting entrepreneurial innovation in inner cities, blog on innovation', Harvard Business Review, 5 June [online] https://hbr.org/2012/06/planting-entrepreneurialinnov (accessed 5 May 2018).

Laitinen, I., Osborne, M. and Stenvall, J. (2016) 'Complex regional innovation networks and HEI engagement-the case of Chicago', International Journal of Knowledge-Based Development, Vol. 7, No. 2, pp.184-201.

Mas-Verdú, F., Ribeiro-Soriano, D. and Roig-Tierno, N. (2015) 'Firm survival: the role of incubators and business characteristics', Journal of Business Research, Vol. 68, No. 4, pp.793-796.

McCann, P. and Ortega-Argilés, R. (2011) Smart Specialisation, Regional Growth and Applications to EU Cohesion Policy, IEB Working Paper 2011/14.

Mieszkowski, K. and Kardas, M. (2015) 'Facilitating an entrepreneurial discovery process for smart specialisation. The case of Poland', Journal of the Knowledge Economy, Vol. 6, No. 2, pp.357-384.

OECD (2013) Entrepreneurial Ecosystems and Growth Oriented Entrepreneurship, OECD, Paris [online] http://www.oecd.org/cfe/leed/entrepreneurial-ecosystems.pdf (accessed 5 May 2018).

Oxford University Innovation Ltd. (2016) 'Business creation - incubation and acceleration', Presentation at the Macro-Regional Innovation Week Trieste, Italy, 28 September [online] https://ec.europa.eu/jrc/sites/jrcsh/files/20160928-macroregional-innovation-hart_en.pdf (accessed 5 May 2018). 
Romano, A., Passiante, G., Del Vecchio, P. and Secundo, G. (2014) 'The innovation ecosystem as booster for the innovative entrepreneurship in the smart specialisation strategy', International Journal of Knowledge-Based Development, Vol. 5, No. 3, pp.271-288.

Secundo, G., Vecchio, P. D. and Passiante, G. (2015) 'Creating innovative entrepreneurial mindsets as a lever for knowledge-based regional development', International Journal of KnowledgeBased Development, Vol. 6, No. 4, pp.276-298.

Van Winden, W. and de Carvalho, L. (2018) Can Start-Ups Solve Urban Problems? An Analysis of Amsterdam's 'Start-Up in Residence' Programme, Working Paper, Amsterdam University of Applied Sciences [online] https://www.researchgate.net/publication/ 324748097 CAN STARTUPS SOLVE URBAN PROBLEMS AN ANALYSIS OF AMS TERDAM'S_STARTUP_IN_RESIDENCE_PROḠRAMME (accessed 3 May 2018).

\section{Notes}

$1 \mathrm{http}: / / \mathrm{www}$.founders-founders.com/the-founders-house/

2 https://www.yesdelft.com/ 